\title{
ARMAZENAMENTO DO IOGURTE COMERCIAL E O EFEITO NA PROPORÇÃO DAS BACTÉRIAS LÁCTICAS
}

\author{
ADRIANA FURLAN MARTIN
}

Dissertação apresentada à Escola Superior de Agricultura "Luiz de Queiroz", da Universidade de São Paulo, para obtenção do título de Mestre em Ciências. Área de concentração: Ciência e Tecnologia de Alimentos.

P I R A C I C A B A

Estado de São Paulo - Brasil

Janeiro -2002 


\title{
ARMAZENAMENTO DO IOGURTE COMERCIAL E O EFEITO NA PROPORÇÃO DAS BACTÉRIAS LÁCTICAS
}

\section{ADRIANA FURLAN MARTIN}

Engenheiro Agrônomo

Orientador: PROF. DR. JORGE HORII

\begin{abstract}
Dissertação apresentada à Escola Superior de Agricultura "Luiz de Queiroz", da Universidade de São Paulo, para obtenção do título de Mestre em Ciências. Área de concentração: Ciência e Tecnologia de Alimentos.
\end{abstract}

P I R A C I C A B A

Estado de São Paulo - Brasil

Janeiro - 2002 
Dados Internacionais de Catalogação na Publicação (CIP)

DIVISÃO DE BIBLIOTECA E DOCUMENTAÇÃO - ESALQ/USP

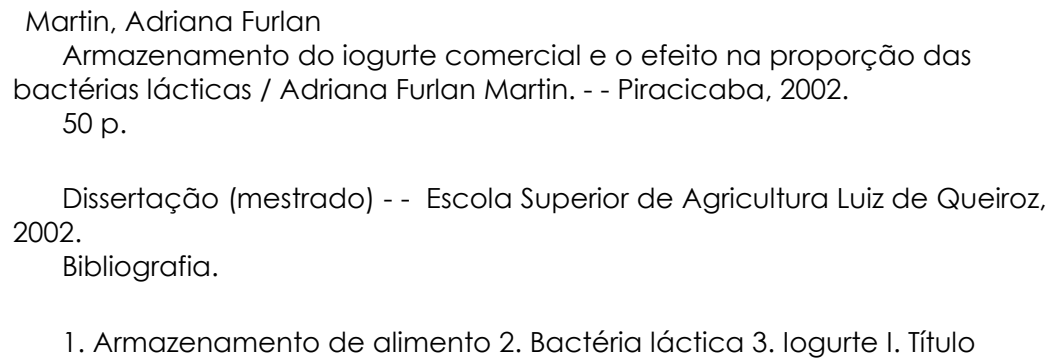

CDD 637.146

\section{"Permitida a cópia total ou parcial deste documento, desde que citada a fonte - $O$ autor"}


Ao ROGÉRIO,

pelo apoio, paciência e amor demonstrados,

Dedico 
Aos meus pais ROBERTO e MARLENE e às minhas irmãs GRAZIELA e MARIANA, pela compreensão e apoio, 


\section{AGRADECIMENTOS}

A Deus, que guiou meus passos em mais uma etapa de minha vida e sem Ele nada teria sido possível.

A todos aqueles que de alguma forma contribuíram para a concretização deste trabalho, minha profunda gratidão, respeito e admiração e, particularmente:

Ao Prof. Dr. Jorge Horii, pela orientação, apoio e incentivo constante ao longo deste trabalho.

Ao Prof. Dr. Antonio Joaquim de Oliveira pela orientação, amizade e colaboração na realização deste trabalho.

Ao Prof. Dr. André Ricardo Alcarde, pelas correções e colaboração.

À Escola Superior de Agricultura "Luiz de Queiroz", em especial ao Departamento de Agroindústria, Alimentos e Nutrição, pelos recursos oferecidos.

À Coordenação de Aperfeiçoamento de Pessoal de Nível Superior (CAPES), pela concessão da bolsa de estudo.

Aos funcionários do Depto. de Agroindústria, em especial à amiga Cleomar Maria de Carvalho, pela colaboração na etapa prática deste trabalho, Vana, Rosemary, Silvino, Rubens, pela atenção e colaboração.

Aos professores do Curso de Mestrado em Ciência e Tecnologia de Alimentos pelo enriquecimento pessoal e profissional que trouxeram à minha vida.

Aos colegas do Curso de Pós - Graduação, em especial a André, Antonio, Denise, Giovana, Juliana, Marilisa, Patrícia, pela convivência, incentivo e alegrias compartilhadas. 
Às bibliotecárias Beatriz Helena Giongo e Mídiam Gustinelli pela colaboração nas correções.

À grande amiga Solange Ap. Groppo Blumer pela amizade, apoio, incentivo e dedicação, facilitando, em todas as etapas, a execução deste trabalho.

Às queridas Angela e Soninha pelo apoio, incentivo e colaboração. 


\section{SUMÁRIO}

Página

LISTA DE FIGURAS …................................................................... ix

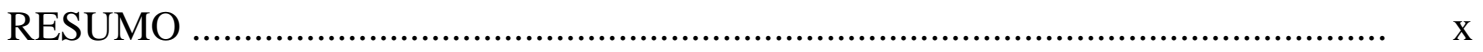

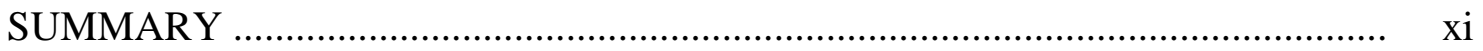

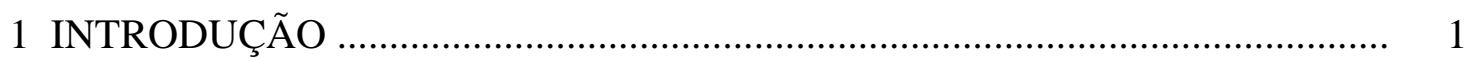

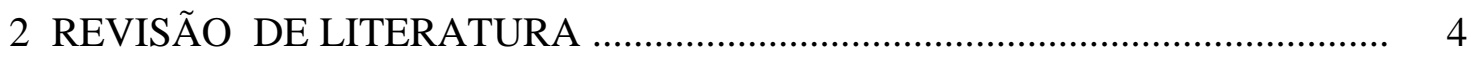

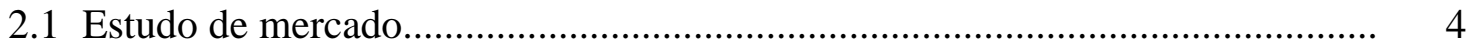

2.2 Composição, Valor Nutritivo e Terapêutico .................................................. 5

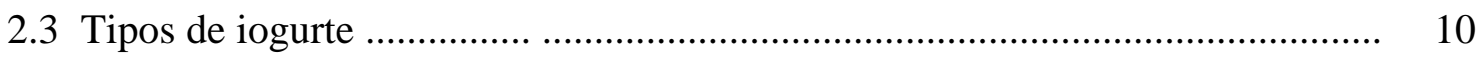

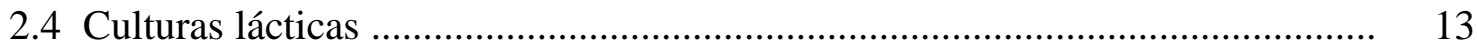

2.5 Alterações durante o armazenamento ......................................................... 14

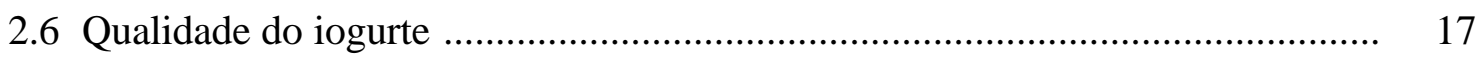

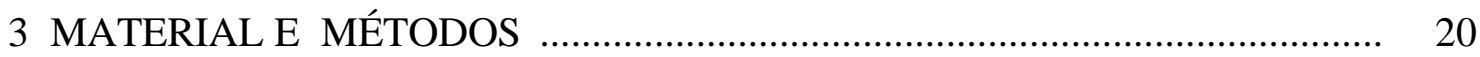

3.1 Aquisição das amostras ........................................................................ 20

3.2 Preparo das amostras para análises........................................................... 20

3.3 Peso bruto e peso líquido ....................................................................... 21

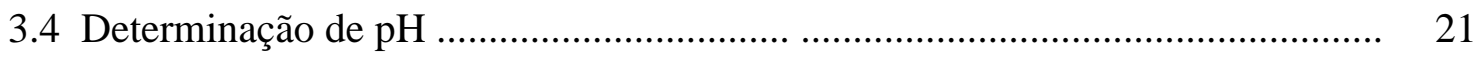

3.5 Determinação da acidez titulável ............................................................ 21

3.6 Contagem de Streptococcus sp e Lactobacillus sp (em UFC/mL) ................... 21 
3.7 Contagem de microrganismos psicrotróficos (em UFC/mL) .......................... 22

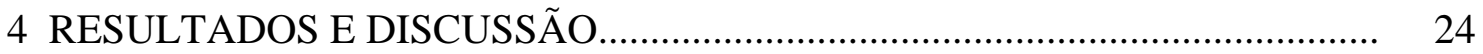

4.1 Peso bruto e peso líquido dos produtos..................................................... 24

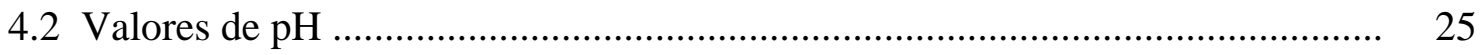

4.3 Acidez Titulável .................................................................................. 28

4.4 Contagem de Streptococcus sp e Lactobacillus sp (em UFC/mL) ................. 30

4.5 Contagem de microrganismos psicrotróficos ............................................... 34

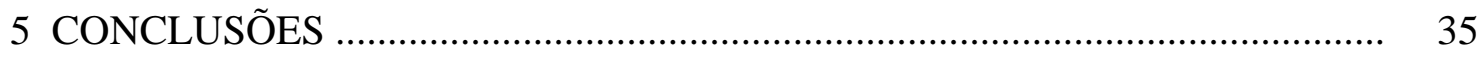

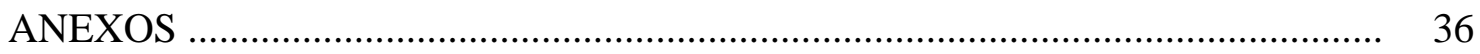

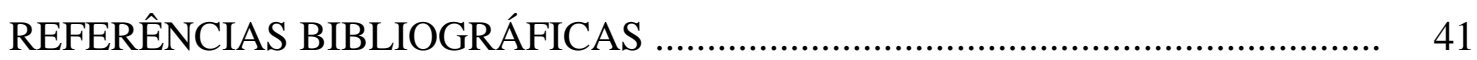




\section{LISTA DE FIGURAS}

Página

1 Fluxograma do processamento do iogurte tradicional

2 Valores de $\mathrm{pH}$ nas amostras comerciais de iogurte .25

3 Acidez titulável, em \% de ácido láctico, de amostras de iogurte .28

$4 \mathrm{UFC} / \mathrm{ml}$ de Streptococcus sp e Lactobacillus sp .32 


\title{
ARMAZENAMENTO DO IOGURTE COMERCIAL E O EFEITO NA PROPORÇÃO DAS BACTÉRIAS LÁCTICAS
}

\author{
Autora: ADRIANA FURLAN MARTIN \\ Orientador: Prof. Dr. JORGE HORII
}

\section{RESUMO}

Os objetivos desta pesquisa foram verificar a proporção entre Streptococcus salivarius subsp. thermophilus e Lactobacillus delbrueckii subsp. bulgaricus em iogurte natural, comercial e os efeitos do armazenamento (dentro do prazo de validade) sobre a proporção das bactérias lácticas componentes do produto, o $\mathrm{pH}$, a acidez e a presença de microrganismos psicrófilos. As amostras de iogurte foram adquiridas por trinta dias consecutivos, num total de 30 amostras, de um mesmo lote, e submetidas às análises de $\mathrm{pH}$, acidez titulável e contagem, em meio TPPY - Eriocromo-ágar, de Lactobacillus sp. e Streptococcus sp. (em UFC/mL). Os resultados mostraram que, durante o armazenamento, ocorreram variações nas características físico-químicas do iogurte, como $\mathrm{pH}$ que variou de 4,36, inicialmente, para 4,18, e acidez titulável que variou de 0,73\% (em ácido láctico) para 1,17\%. Streptococcus salivarius subsp. thermophilus e Lactobacillus delbrueckii subsp. bulgaricus foram encontrados na proporção de 2:1, respectivamente, diminuindo para 1:1 devido, provavelmente, às variações de $\mathrm{pH}$ e acidez titulável durante o armazenamento, por trinta dias, que corresponde ao prazo de validade. 


\title{
EFFECT OF THE PERIOD OF STORAGE ON THE PROPORTION OF LACTIC BACTERIA IN COMMERCIAL YOGURT
}

\author{
Author: ADRIANA FURLAN MARTIN \\ Adviser: Prof. Dr. JORGE HORII
}

\section{SUMMARY}

The objectives of this research were to verify the proportion of Streptococcus salivarius subsp. thermophilus to Lactobacillus delbrueckii subsp. bulgaricus in commercial natural yogurt and evaluate the effect of the period of storage in some characteristics of the product, such as proportion of lactic bacteria, $\mathrm{pH}$, acidity and presence of psychrophiles microorganisms. Yogurts from the same lot were analysed during a period of 30 consecutive days, within the best before date. One sample a day was analysed for $\mathrm{pH}$, acidity and bacterial count (c.f.u./ml) of Streptococcus sp. and Lactobacillus sp. in broth TPPY-Eriochrome-agar. Results indicated that significant changes on physical-chemical characteristics of the yogurt occured during the storage of the product. The $\mathrm{pH}$ decreased from 4.36 to 4.18 and the acidity increased from $0.73 \%$ (lactic acid) to $1.17 \%$ during the period of storage. The proportion of Streptococcus salivarius subsp. thermophilus to Lactobacillus delbrueckii subsp. bulgaricus during the period of storage varied from $2: 1$ to $1: 1$, respectively, probably because of the variations of $\mathrm{pH}$ and acidity during these 30 days. 


\section{INTRODUÇÃO}

O iogurte é o mais antigo produto lácteo fermentado, tendo sido citado na Bíblia, quando, segundo a mesma, Abraão recebeu instruções de um anjo para curar sua esposa Sara, utilizando leite de cabra fermentado.

Acredita-se que o iogurte é ainda mais antigo que a Bíblia e, embora não haja nenhum registro disponível com relação à sua origem, esta deve ter ocorrido em regiões montanhosas próximas ao Mediterrâneo, pois os povos nômades, destas regiões, atravessavam o deserto levando o leite "in natura" acondicionado em bolsas confeccionadas com pele de cabra, e transportadas por camelos. O contato das bolsas com o corpo dos camelos oferecia condições ótimas de temperatura para o crescimento de bactérias produtoras de ácido láctico. Ao consumir o leite, os nômades encontravam um produto de sabor agradável, que não se deteriorava com a mesma facilidade que o leite. Essa preparação passou, então, a ser transmitida de pai para filho (Silva, 1985).

O termo iogurte é derivado da palavra "jugurt", mas recebe diferentes designações de acordo com as regiões do mundo, como na Bulgária, onde sua importância é muito significativa na dieta, e é chamado de "yaourt" (Salado \& Andrade, 1989). O iogurte, ou coalhada búlgara, é elaborado em vários países da Europa Oriental (Turquia, Bulgária, Grécia, Romênia) e Arábia, sendo considerado, nessas regiões, um alimento popular, de grande digestibilidade, com aroma e paladar peculiares (Behmer, 1991). A fermentação do leite é feita em muitos países no mundo, por diferentes métodos, resultando em vários produtos de leite fermentado, sendo o iogurte o mais comum e também o mais consumido. Os produtos variam, consideravelmente, em composição, "flavor" e textura, de acordo com a natureza dos microrganismos 
fermentadores, do tipo de leite e do processo usado na fabricação (Deeth \& Tamime, 1981).

Este produto é definido pelo Regulamento da Inspeção Industrial de Produtos de Origem Animal - RIISPOA, como o produto adicionado ou não de outras substâncias alimentícias, obtido por coagulação e diminuição do pH do leite, ou leite reconstituído, adicionado, ou não, de outros produtos lácteos, por fermentação láctea mediante a ação proto-simbiótica de Lactobacillus delbrueckii subsp bulgaricus e Streptococcus salivarius subsp thermophilus, aos quais pode se acompanhar, de forma complementar, outras bactérias ácido-lácticas que, por sua atividade, contribuem para a determinação das características do produto final (Brasil, 1998). O iogurte, segundo Caruso \& Oliveira (1984) é um produto comprovadamente, reconhecido como de alta qualidade organoléptica, e considerado um "produto vivo" uma vez que contém até cinco bilhões de células por grama.

Os primeiros iogurtes comerciais foram produzidos na França e na Espanha em 1920, e nos Estados Unidos, em 1940, mas somente a partir da década de 1960 é que houve um aumento no consumo deste produto, devido a melhorias nas técnicas de processamento, reconhecimento da qualidade nutritiva e da função terapêutica. No Brasil, o iogurte foi introduzido nos anos 30, com a imigração européia, a partir de um pequeno grupo de consumidores (Tamime \& Robinson, 1985).

A crescente procura por alimentos altamente nutritivos, que desempenhem funções terapêuticas (alimentos funcionais), está gerando um aumento no consumo de iogurtes em geral. Este produto requer o controle adequado de uma série de condições, desde seu processamento até sua comercialização, para que se tenha assegurada a qualidade do iogurte (Saboya et al., 1997).

Qualquer produto comercial alimentício deve, por legislação, ser armazenado em condições adequadas que garantam a manutenção das características originais do produto. A qualidade passou a ser considerada a chave para o sucesso em qualquer ramo de atividade como forma de manter-se em níveis de competitividade. O consumidor tem se mostrado mais atento e consciente ao adquirir um produto, exigindo qualidade: na embalagem, composição e valor nutricional. O Mercosul incentiva a competitividade, 
estabelecendo padrões de qualidade mais modernos e exigentes, visando oferecer ao consumidor um produto mais confiável (Ferreira \& Chaves, 1981; Penna et al., 1994; Tamime \& Robinson, 1985).

Considerando-se que o iogurte requer condições adequadas para seu armazenamento e que estas podem apresentar influência na manutenção das características do produto, justifica-se a importância deste trabalho.

Na presente pesquisa foi verificada a proporção entre Streptococcus salivarius subsp. thermophilus e Lactobacillus delbruecki subsp. bulgaricus em iogurte natural comercial e os efeitos do armazenamento (dentro do prazo de validade) sobre as bactérias lácticas componentes do produto, o pH, a acidez e presença de psicrófilos. 


\section{REVISÃO DE LITERATURA}

\subsection{Estudo de mercado}

O potencial de crescimento do mercado de iogurte no Brasil é grande. $\mathrm{O}$ brasileiro consome cerca de $2 \mathrm{~kg}$ de produtos refrigerados per capita, incluindo iogurtes, bebidas e sobremesas lácteas (Consumo..., 1997). Esse valor é baixo, quando comparado ao de outros países, como o Chile, onde o consumo é de $8 \mathrm{~kg}$ ao ano; a França tem um consumo, per capita, de $25 \mathrm{~kg}$; a Irlanda de $18 \mathrm{~kg}$ e na Bulgária, o consumo está em torno de $31 \mathrm{~kg}$ (Brandão, 1995; Iogurtes..., 1995). Uma das causas do baixo consumo de iogurte pelos brasileiros é o custo elevado do produto, que, segundo a Associação Brasileira das Indústrias de Iogurtes, não advém do processo produtivo, mas da carga tributária. Outra causa do baixo consumo é o hábito de se realizar compras uma vez ao mês, ocasionando a preferência por produtos com prazo de validade prolongado, o que não é o caso do iogurte (Penna et al., 1994).

Além disso, o iogurte e seus similares são considerados pelos consumidores como alimento supérfluo e não como um alimento básico. O principal produto comercial é o tradicional iogurte de polpas de frutas, representando 33\% do mercado. As bebidas lácteas, à base de iogurte, apresentam um grau de acidez menor e adaptam-se melhor ao paladar brasileiro. Após cinco anos de seu lançamento já são responsáveis por um crescimento de $17 \%$ do mercado. A embalagem também tem influenciado o aumento de consumo, devido à apresentação do produto em embalagens de 1 litro, constituídas de sacos plásticos, embalagens de vidro ou "Tetra Pak", onde os produtos, por serem pasteurizados, apresentam validade de 30 dias, e têm preço mais acessível. O mercado 
brasileiro de iogurte está em pleno crescimento, devido à participação de empresas de alto nível e alta competitividade (Consumo..., 1997; Iogurtes..., 1995).

\subsection{Composição, Valor Nutritivo e Terapêutico.}

Para se conhecer a composição do iogurte é necessário que se conheça antes a composição de sua principal matéria-prima, o leite.

O leite é uma emulsão de cor branca, ligeiramente amarelada, de odor suave e sabor adocicado, secretado pelas glândulas mamárias das fêmeas dos mamíferos (Brasil, 1980). Segundo Behmer (1984), o leite é uma emulsão de glóbulos graxos, estabilizada por substâncias albuminóides, em um soro que contém: açúcar - a lactose - matérias protéicas, sais minerais e orgânicos, e pequenas quantidades de vários produtos, como lecitina, uréia, aminoácidos, ácido cítrico, ácido láctico, ácido acético, álcool, lactocromo, vitaminas e enzimas.

Por ser a matéria-prima de maior importância na fabricação de iogurtes, o leite deve ser da mais alta qualidade para que o produto final apresente características desejáveis e maior vida útil. Para isso, deve ser livre de bacteriófagos, soluções de

limpeza e desinfetantes, isento de contaminantes e apresentar uma baixa contagem de células somáticas e bactérias que poderiam dificultar o desenvolvimento das culturas lácticas usadas no preparo do iogurte (Neirotti \& Oliveira, 1988).

De acordo com o artigo 476 do Regulamento da Inspeção Industrial e Sanitária de Produtos de Origem Animal, do Ministério da Agricultura (Brasil, 1998), o leite, para ser considerado normal, deve apresentar:

- Caracteres normais;

- Teor de gordura mínimo de 3\%;

- Acidez, em graus Dornic, entre 15 e 20;

- Densidade, a $15^{\circ} \mathrm{C}$, entre 1028 e 1033 ;

- Lactose - mínimo de 4,3\%; 
- Extrato seco desengordurado - mínimo de 8,5\%;

- Extrato seco total - mínimo de $11,5 \%$;

- Índice crioscópico - mínimo de $-0,55^{\circ} \mathrm{C}$;

- Índice refratométrico, no soro cúprico a $20^{\circ} \mathrm{C}$, não inferior a $37^{\circ}$ Zeiss.

Segundo Neirotti \& Oliveira (1988), a composição do leite de vaca varia segundo vários aspectos como raça, manejo, alimentação, tendo em média $87 \%$ de umidade; 3,5 - 3,7\% de lipídeos; 3,7\% de proteínas (caseína, albumina e globulina); 4,8\% de lactose; $0,20 \%$ de ácidos láctico, cítrico e acético e 0,6\% de cinza.

A composição do iogurte é similar à do leite, embora se reconheça que há algumas diferenças devido a mudanças ocorridas pela fermentação bacteriana sobre a lactose e pela adição de leite em pó, normalmente feita para aumentar os sólidos do leite, o que permite maior conteúdo protéico, além da presença de aditivos e flavorizantes (Deeth \& Tamime, 1981).

Os componentes normalmente presentes no iogurte de frutas, de acordo com Brandão (1995), são os seguintes: lipídeos: 1,5\%; lactose: 3 - 4,5\%; estabilizantes: 0,3 $0,5 \%$ e sólidos totais: $12-16 \%$.

O mesmo autor ressalta que os estabilizantes utilizados nos iogurtes são a gelatina, a pectina e o ágar-ágar. A adição de leite em pó ou de concentrados protéicos, como os caseinatos com objetivos sensoriais, também contribui na melhoria do valor nutricional do iogurte.

De acordo com Salado \& Andrade (1989), os constituintes do leite sofrem uma série de alterações durante a fabricação do iogurte, principalmente as proteínas, gorduras, vitaminas, entre outros. Durante o processo de fabricação do iogurte, o teor de aminoácidos livres e peptídeos aumenta, em relação aos teores presentes no leite "in natura". A gordura do leite é quebrada através das lipases produzidas pelas bactérias lácticas, liberando ácidos graxos e glicerol, podendo ser degradados em outros compostos. Durante o processamento, os teores de alguns ácidos graxos aumentam e outros diminuem. 
Os teores de vitaminas, principalmente as do complexo B, podem aumentar ou diminuir, de acordo com o metabolismo das bactérias lácticas. Os dados sobre as vitaminas não são uniformes e variam segundo a fonte consultada (Gurgel et al., 1992; Salado \& Andrade, 1989; Tamime \& Robinson, 1985).

O iogurte possui 10 vezes mais ácido fólico que o leite utilizado na elaboração. As principais vitaminas, em unidades/100g, presentes no iogurte de leite desnatado são: vitamina $A, 70$; vitamina $B_{1}, 42$; vitamina $B_{2}, 200$; vitamina $B_{6}$, 46; vitamina $B_{12}, 0,23$; vitamina C, 0,7; ácido fólico, 4,1; ácido nicotínico, 125; ácido pantotênico, 381; biotina, 2,6; e colina, 0,6 (Tamime et al., 1985). Durante a acidificação biológica do leite, o ácido cítrico diminui de 25 a 35\%, o ácido láctico aumenta cerca de $60 \%$ e o ácido acético aumenta cerca de 5\% (Salado \& Andrade, 1989).

O iogurte é um alimento altamente nutritivo, rico em proteínas, cálcio e fósforo, recomendado para gestantes e lactantes, além de pessoas idosas, que necessitam da reposição de cálcio. Seu valor nutritivo é semelhante ao do leite utilizado em seu preparo, adicionado dos nutrientes metabolizados pelos microrganismos envolvidos no processo de fermentação (Tamime \& Deeth, 1980).

De acordo com Pombo et al. (1983), o iogurte consiste em um gel firme e fino, resultante da fermentação da lactose em ácido láctico, o que ocasiona queda do pH e causa progressiva solubilização do fosfato-citrato de cálcio e agregação da caseína.

Devido à ação metabólica das bactérias sobre os componentes do leite, estes são transformados em substâncias mais simples, podendo ser consumidos por pessoas que, devido à deficiência da enzima lactase em seu organismo, não toleram a lactose presente no leite, uma vez que esta é reduzida durante a fermentação (Salado \& Andrade, 1989).

Para Kleinman (1990) indivíduos podem aumentar sua tolerância a produtos lácteos por ingestão de produtos fermentados como o iogurte. A lactose ingerida no iogurte é mais efetivamente digerida que a lactose do leite, ainda que o iogurte tenha quantidade equivalente em lactose. Lin et al. (1991) atribuem esse fato à hidrólise intestinal, pela ação da $\beta$-galactosidase microbiana dos organismos presentes no iogurte, durante a passagem através do trato gastrointestinal. Brandão (1995) ressaltou que a lactose presente no iogurte é mais facilmente digerível, pois cerca de $50 \%$ de sua 
concentração original já foi hidrolisada durante a fermentação e, quando as células bacterianas, durante o processo de metabolismo do organismo humano, sob condições de digestão gástrica, sofrem "lise", liberam lactase.

A homogeneização do leite para o preparo do iogurte quebra os glóbulos de gordura em partículas menores, o que facilita sua digestão. As lipases bacterianas hidrolisam as gorduras, resultando em ácidos graxos livres, o que facilita a sua absorção (Gurgel, 1994; Saboya et al., 1997).

Blumer (1989) citou estudos que comparam a digestibilidade do iogurte e a do leite e esclarecem que $32 \%$ do leite é digerido em 1 hora; $36 \%$ do mesmo é digerido em 2 horas e $44 \%$ é digerido em 3 horas. No caso do iogurte, $91 \%$ do mesmo é digerido em 1 hora; $92 \%$ é digerido em 2 horas e 96,5\% é digerido em 3 horas. Essas diferenças na digestibilidade foram atribuídas às mudanças químicas da proteína, durante a fermentação.

Brandão (1995) relatou que a digestibilidade das proteínas no iogurte é aumentada devido a diversos fatores como: o tratamento térmico mais intenso; alta acidez e conseqüente menor coagulação das proteínas; secreção de enzimas digestivas das glândulas salivares, estimulada pelas partículas de proteínas coaguladas; homogeneização; aumento do teor de peptídeos e aminoácidos livres.

Ferreira (1981) ressaltou a ação dos microrganismos envolvidos no processo fermentativo que leva ao aumento do teor de niacina no produto final. Além deste fato, o abaixamento do pH pela produção de ácido láctico, a ação inibidora de germes indesejáveis, advinda da produção de ácidos orgânicos e outros metabólitos pelos organismos envolvidos, além da presença da própria bactéria láctica atuando no trato intestinal, são considerados essenciais para a ação benéfica proveniente do consumo de iogurtes.

Salado \& Andrade (1989) discutiram que as bactérias do ácido láctico têm efeito antagônico sobre o crescimento de vários microrganismos devido aos produtos resultantes do metabolismo e das diferentes atividades bioquímicas. O ácido produzido pelas bactérias lácticas apresenta efeito bacteriostático e bactericida contra microrganismos sensíveis, principalmente bactérias esporogênicas. 
Compostos antibacterianos (antibióticos naturais produzidos por Lactobacillus bulgaricus) contra Salmonella, Shigella, Pseudomonas e Escherichia coli têm sido reportados na literatura (Brandão, 1995).

Foster et al. (1980) sugeriram que os lactobacilos do iogurte podem prevenir diarréias enteropatogênicas, associadas ao uso prolongado de antibióticos. Deeth \& Tamime (1981) enfatizaram que o iogurte deve ser usado para prevenir e tratar desordens gastrointestinais, principalmente em crianças, acompanhando terapias com antibióticos. De acordo com Brandão (1995), os streptococos do iogurte são mortos imediatamente à chegada deles ao trato intestinal humano, devido às condições de acidez gástrica e da presença de sais biliares no duodeno. Os lactobacilos são um pouco mais resistentes que os streptococos e sobrevivem por mais tempo que estes. Acredita-se, porém, que os microrganismos do iogurte não conseguem se implantar na flora intestinal humana.

A hipercolesterolemia predispõe indivíduos às doenças artereoscleróticas, e tem sido amplamente aceito que a dieta tem um importante papel na redução do colesterol. Alguns pesquisadores sugeriram que a arterosclerose pode regredir, em pacientes hipercolesterolêmicos, suplementando-se a dieta com iogurte (Saboya et al., 1997). O ácido hidroximetilglutárico, resultante da ação das bactérias lácticas, e presente no iogurte, pode limitar a síntese de colesterol no organismo ao inibir a enzima hidroximetilglutárico-coenzima A-redutase (Gurgel, 1994).

Saboya et al. (1997) ressaltaram que os lactobacilos do iogurte causam desconjugação ou dehidroxilação dos sais biliares no intestino delgado, causando consequiente perda de ácidos biliares, não podendo ser reciclados. Devido a isso, o organismo usa mais colesterol para fabricar sais biliares, diminuindo o nível de colesterol sérico. Brandão (1995) apontou como fatores responsáveis pelos efeitos hipocolesterolêmicos do iogurte a inibição da síntese de colesterol a partir do acetato, a presença de hidroximetilglutarato (fator inibitório de síntese de colesterol) e as presenças de cálcio, ácido orótico, lactose e caseína.

O Lactobacillus bulgaricus tem sido relacionado a fatores anticarcinogênicos. A ingestão de iogurte por ratos demonstrou inibir o crescimento de tumor, apresentando 
uma relação direta entre a quantidade de iogurte consumido e o efeito inibidor (Brandão, 1995).

De acordo com Saboya et al. (1997) as propriedades anticarcinogênicas de microrganismos do iogurte e outras floras lácticas podem ser classificadas em eliminação de pró-carcinógenos, modulação de enzimas pró-carcinogênicas e supressão de tumor.

\subsection{Tipos de iogurte}

Há vários tipos de iogurte no mercado, variando quanto a composição, sabor, consistência e valor calórico ("diet" e/ou "light"). Os tipos de iogurte variam, também, de acordo com o método empregado na produção e a natureza do processo de pósincubação (Rasic \& Kurmann, 1978). O padrão legal proposto, pela FAO, citado por Blumer (1989), para a composição química do iogurte, em vários países, é baseado no teor de gordura contido no produto (se alto, médio ou baixo). Para Tamime \& Deeth (1980) o iogurte pode ser classificado em sólido ou homogêneo, de acordo com a consistência resultante da coagulação da proteína e o modo de produção.

- Iogurte sólido (ou firme): quando o coágulo é formado pela fermentação, dentro da própria embalagem de venda, e o iogurte tem uma massa contínua semisólida. O embalamento é feito após a inoculação do fermento.

- Iogurte homogêneo (ou batido): formado por uma massa com estrutura de gel, que é quebrada após o resfriamento seguido do embalamento. O produto é resfriado e batido antes de ser envasado.

- Iogurte homogêneo de baixa viscosidade (ou líquido): pode ser produzido misturando-se o homogêneo com outra mistura de poucos sólidos totais. O coágulo se rompe até alcançar uma fórmula líquida antes do embalamento. A principal característica é a separação de sólidos em suas fases, devido à mistura de água em sua preparação. 
O processamento do iogurte difere segundo os diversos tipos de produto a serem obtidos, conforme se pode verificar na Figura 1 (Abreu, 1997).

Para Salado \& Andrade (1989), há três tipos de iogurte classificados segundo o aroma que apresentam em:

- Iogurte natural: é o iogurte tradicional com seu típico sabor ácido acentuado;

- Iogurte com frutas: é produzido por adição de frutas, usualmente frutas naturais, congeladas, purês, polpas, pedaços ou geléias de frutas;

- Iogurte aromatizado: preparado por adição, ao iogurte natural, de açúcar e outros agentes adoçantes, saborizantes e corantes sintéticos.

Ainda, segundo os mesmos autores, a incubação depois do processamento pode diferenciar os vários tipos de iogurte em: iogurte pasteurizado, iogurte concentrado, iogurte congelado e iogurte em pó ("Spray Dried").

Além dessas classificações, outros tipos de iogurte vêm sendo lançados no mercado, como iogurte tipo Suíço, tipo "Sundae”, e uma infinidade de bebidas lácteas, dificultando sua classificação (Brandão, 1995). 


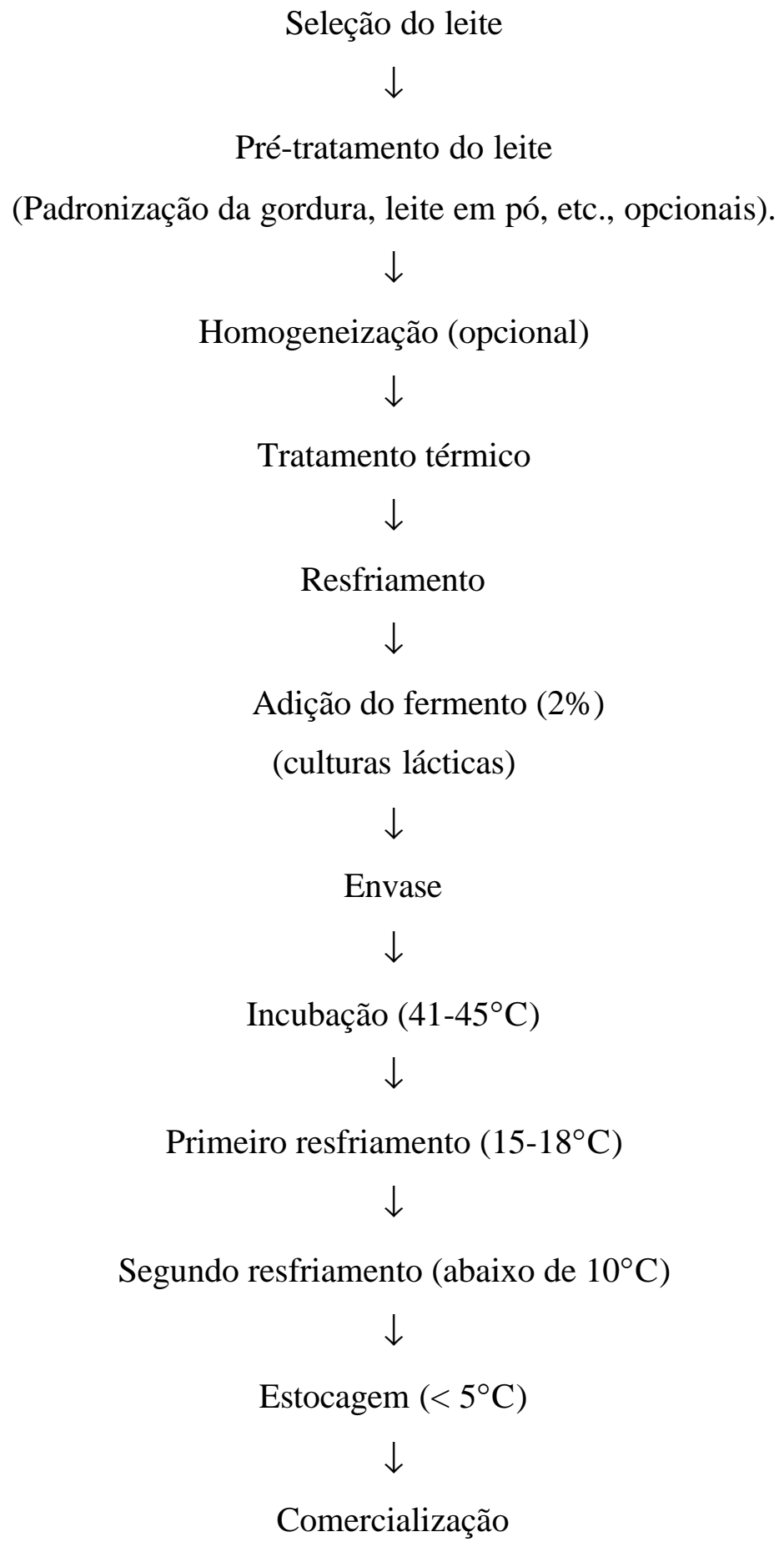

Figura 1- Fluxograma do processamento do iogurte tradicional - Fonte: Abreu (1997). 


\subsection{Culturas lácticas}

A produção do iogurte envolve, basicamente, uma cultura láctica mista composta por Lactobacillus delbrueckii subsp. bulgaricus e Streptococcus salivarius subsp. thermophilus. Ambas são homofermentativas, produtoras de ácido láctico (Silva, 1974).

O Lactobacillus delbrueckii subsp. bulgaricus apresenta-se como bastonetes, unidos em cadeias longas, com crescimento ótimo em temperaturas entre 45 e $50^{\circ} \mathrm{C}$, mas crescem em temperaturas de até $-15^{\circ} \mathrm{C}$. O Streptococcus salivarius subsp. thermophilus apresenta-se como cocos unidos, geralmente, em cadeias curtas, e seu melhor crescimento se dá em temperaturas entre 37 e $45^{\circ} \mathrm{C}$ (Dellaglio et al., 1992; Robinson \& Tamime, 1975; Saboya et al., 1997).

A temperatura ideal de incubação da cultura láctica é de $42^{\circ} \mathrm{C}$ para a maioria dos autores consultados (Araújo et al., 1986; Loewenstein et al., 1980; Neirotti \& Oliveira, 1988). Radke-Mitchell \& Sandini (1986) verificaram que as cepas de Streptococcus salivarius subsp. thermophilus obtiveram maior número de células que o Lactobacillus delbrueckii subsp. bulgaricus às temperaturas de $37^{\circ} \mathrm{C}, 42^{\circ} \mathrm{C}$ e $45^{\circ} \mathrm{C}$, em 93,3\% das culturas mistas testadas. As temperaturas ótimas de crescimento não exercem influência sobre o crescimento da cultura mista composta pelos microrganismos em questão, porém, a temperatura influenciou a compatibilidade das culturas, porque determinou a concentração ou tipos de fatores estimulatórios produzidos pelo Lactobacillus delbrueckii subsp. bulgaricus.

O bom desenvolvimento durante o processo de fermentação do leite, para produção de iogurte, se deve, basicamente, à capacidade simbiótica (protocooperação) das bactérias em questão. O crescimento de Streptococcus salivarius subsp. thermophilus é estimulado pelos aminoácidos livres e peptídeos liberados pelos lactobacilos a partir das proteínas do leite. Por outro lado, a produção de ácido fórmico pelos lactobacilos, é estimulada por compostos produzidos pelos lactococos, em ausência ou baixa concentração de oxigênio. O ácido fórmico produzido limita o 
crescimento dos lactobacilos, juntamente com o dióxido de carbono produzido pelos lactococos (Driessen et al., 1982).

Os lactococos e os lactobacilos apresentam, ainda, resistência à degeneração, poder acidificante médio, e produzem substâncias responsáveis pela viscosidade, sabor e aroma, característicos do iogurte (Souza, 1996).

\subsection{Alterações durante o armazenamento}

$\mathrm{O}$ teor da maioria das vitaminas presente no iogurte diminui durante o armazenamento a $5^{\circ} \mathrm{C}$ por 16 dias, principalmente, os teores de $\mathrm{B}_{12}(28,6 \%)$ e ácido fólico $(59,9 \%)$. Os teores de biotina, niacina e ácido pantotênico diminuem muito pouco (Reddy et al., 1972).

A hidrólise das proteínas do iogurte, por microrganismos, é acompanhada pela produção de sabor amargo, devido à formação de polipeptídeos e está diretamente relacionada ao $\mathrm{pH}$, temperatura e tempo de armazenamento do produto. Uma oscilação na temperatura, durante o período de armazenamento, pode propiciar o desenvolvimento de psicrotróficos, que crescem sob temperaturas de refrigeração, alterando as características do iogurte (Moreno \& Kosikowski, 1973). Uma proteólise muito intensa pode apresentar defeitos no produto como acidez excessiva, sabor amargo e diminuição da consistência do iogurte (Souza, 1996).

Tamime \& Robinson (1988) apontaram que os produtos resultantes da proteólise, durante o armazenamento, dependem dos componentes da fração protéica do leite e do tipo de enzimas proteolíticas dominantes no iogurte, pois se a dominância for de polipeptidases, o resultado será polipeptídeos, e se for de peptidases, resultará em aminoácidos livres. Ainda, segundo os mesmos autores, quando ocorre a hidrólise de peptídeos, pode-se observar que: 
- A atividade mais intensa ocorre na fase log;

- A proporção entre as culturas pode afetar o nível de aminoácidos no iogurte, sendo que a predominância de L. delbrueckii subsp. bulgaricus pode desenvolver uma acidificação indesejada ao produto;

- Após 24 horas de armazenamento, o espectro de aminoácidos no iogurte varia em relação à proporção de cocos e bacilos, sendo que na proporção de 1:1 (cocos:bacilos), ocorre formação de $56 \%$ de tirosina, fenilalanina e leucina, e na proporção de 3:1 (cocos : bacilos) são formados $71 \%$ de prolina e aminoácidos livres;

- Na hidrólise de proteínas do leite, os teores de $\mathrm{N}$ não protéico diminuem quando a proporção entre Streptococcus salivarius subsp. thermophilus e Lactobacillus delbrueckii subsp. bulgaricus diminui;

- Ácidos graxos livres podem reduzir a atividade proteolítica da cultura láctica, podendo afetar a textura do coágulo;

- A atividade proteolítica aumenta durante a hidrólise da lactose;

- Leite com bactérias psicrófilas se usado para produção de iogurte, acarretará no aumento, significativo, da atividade proteolítica das culturas, desenvolvendo sabor e aroma inaceitáveis.

Através de estudos da liberação de tirosina e acetaldeídos, alguns autores constataram que culturas puras de Lactobacillus delbrueckii subsp. bulgaricus apresentam maior atividade proteolítica, quando comparadas às culturas puras de Streptococcus salivarius subsp. thermophilus (Singh \& Sharma, 1982; Garcia \& Valle, 1986).

Slocum et al. (1988) demonstraram que a proteólise é dependente da sacarose adicionada ao produto e do tempo de armazenamento, variando de acordo com a cultura usada. Para algumas culturas esse efeito varia de acordo com o teor de gordura do leite. Os autores relataram, também, que o teor de sólidos totais e o tratamento térmico afetam, diretamente, a atividade proteolítica no iogurte, durante o armazenamento. Os mesmos autores estudaram a influência do açúcar na proteólise do iogurte durante a 
incubação e armazenamento, e concluíram que a adição de açúcar associada à temperatura de $4^{\circ} \mathrm{C}$ (na armazenagem) contribuía para a diminuição da atividade proteolítica e melhora da qualidade do produto armazenado.

Embora as culturas lácticas do iogurte apresentem atividade proteolítica fraca, durante a fermentação, a proteólise ocorrida é significativa, podendo provocar alterações físicas na estrutura do iogurte; os aminoácidos e peptídeos formados são precursores de compostos formadores de sabor e aroma do produto (Tamime \& Robinson, 1988).

Gassem \& Frank (1990) afirmaram que o iogurte elaborado com leite, sem tratamento térmico, apresentava aumento significativo de atividade proteolítica, provavelmente, devido às proteinases produzidas por psicrófilos presentes no leite, e obtendo, como conseqüência, um produto de qualidade inferior após armazenamento de 15 dias.

De acordo com Igarashi (1990), a proteólise diminui a temperaturas maiores que $70^{\circ} \mathrm{C}$ por período de $10 \mathrm{~min}$ ou a $75^{\circ} \mathrm{C}$ por $5 \mathrm{~min}$, mas as temperaturas de pasteurização $\left(60^{\circ} \mathrm{C}\right.$ por $30 \mathrm{~min}$. ou $72^{\circ} \mathrm{C}$ por $\left.15 \mathrm{~s}\right)$ não promovem alterações no índice de proteólise. Juffs (1975) analisou a atividade proteolítica dos microrganismos presentes em leite armazenado, em laboratório à temperatura de $5^{\circ} \mathrm{C}$ por $7-8$ dias, através do teor de tirosina e da qualidade organoléptica do produto, e concluiu que o teor de tirosina pode ser indicado para verificar a atividade proteolítica microbiana que ocorre durante o armazenamento comercial de produtos lácteos. Segundo Asperger (1977), o teor de tirosina exerce apenas uma pequena correlação na determinação do sabor e aroma, mas quando presente em teores muito altos $(125 \mu \mathrm{g} / \mathrm{mL})$, as amostras são classificadas como "muito ácidas" ou "ligeiramente ácidas". Teores de tirosina na faixa de 50 a $100 \mu \mathrm{g} / \mathrm{mL}$ estão relacionados a amostras consideradas ricas em sabor e aroma. 


\subsection{Qualidade do iogurte}

O mercado de iogurte é relativamente novo e existem poucas especificações do padrão de qualidade, sendo estas, usualmente, fixadas pelos consumidores e pelos próprios fabricantes (Penna et al., 1994).

O produto iogurte vem passando por uma série de modificações tecnológicas desde seu aparecimento. Atualmente, levando-se em conta, principalmente, os hábitos alimentares e/ou exigências dos diversos mercados consumidores, novos e diferentes produtos, como molhos e temperos à base de iogurte, vem sendo desenvolvidos ou já são encontrados à disposição do consumidor, sendo submetidos a tratamento térmico após sua fabricação, para maior vida de prateleira (Boudier et al., 1989).

Segundo Neirotti \& Oliveira (1988), as propriedades físicas mais importantes do iogurte são: viscosidade, consistência e textura. As análises químicas de rotina compreendem o teor de gordura, acidez e pH. Os teores de proteínas, lactose e cinza, são avaliados por métodos padronizados pelas indústrias. Também são realizados testes de detecção de coliformes, um importante indicativo do padrão de higiene da indústria. Além dessas análises, há ainda as análises organolépticas, que compreendem testes de aroma e sabor do produto. Gurgel et al. (1992), ressaltaram que para as análises microbiológicas, o teste mais utilizado é a contagem de células fúngicas e/ou bacterianas.

Para Davis (1970), a acidez, o sabor e aroma, e a cultura "starter" são aspectos considerados relevantes, do ponto de vista de qualidade do produto. Conforme a intensidade da acidez, o produto pode ser classificado em suave ou insípido, e ácido ou muito ácido. A acidez no iogurte varia com a temperatura de incubação, sendo importante ocorrer o desenvolvimento da cultura láctica durante o armazenamento a frio. Salji \& Ismail (1983) relataram que a consistência do iogurte está relacionada com sua acidez, que se altera durante o armazenamento, em maior ou menor grau, dependendo da acidez inicial e da temperatura de estocagem do produto. A Federação Internacional de Laticínios (IDF) estabelece um índice de acidez mínimo, que é de 0,7\% de ácido láctico $(\mathrm{p} / \mathrm{p})$ para o iogurte em sua fase de comercialização. 
Outro aspecto importante para a qualidade do iogurte é o balanço microbiológico entre L. delbrueckii subsp. bulgaricus e $S$. salivarius subsp. thermophilus. O controle da razão entre eles é de grande importância e preserva o balanço entre a acidez, sabor e aroma (Davis, 1970).

Acidez e temperatura de incubação elevadas favorecem os bacilos em relação aos cocos. Com acidez e temperatura de incubação baixas, o inverso ocorre, demonstrando que a proporção final cocos:bacilos é influência das condições durante o processo produtivo do iogurte (Pette \& Lokema, 1951).

A proporção média de bacilos/cocos obtidos em estudo realizado por RadkeMitchell \& Sandini (1986), a $37^{\circ} \mathrm{C}, 42^{\circ} \mathrm{C}$ e $45^{\circ} \mathrm{C}$ foi de 1:22, 1:8 e 1:2,4, respectivamente.

Há uma grande controvérsia entre os autores quanto ao valor ideal de acidez e pH, para Humphreys \& Plunkett (1969), a acidez deve ser de 1,0 a 1,25\% e o pH de 3,7 a 3,8; para Ginslov (1970), a acidez deve ser menor que 1,2\%; Moreno \& Kosikowski (1973) defenderam um pH de aproximadamente 4,4; Kroger (1976), afirma que um pH na faixa de 3,9 e 4,1 confere ao produto um sabor desagradável. Gavin (1966) estocou o iogurte a $4^{\circ} \mathrm{C}$ e verificou que ao final de 6 dias, o $\mathrm{pH}$ baixou de 4,15 para 3,98, sendo que no iogurte tipo suave, baixou de 4,62 para 4,15. Outros estudos foram realizados por Tealdo et al. (1989), onde iogurtes comerciais foram armazenados a $4^{\circ} \mathrm{C}$ por 30 dias; os autores observaram que o iogurte natural apresentou um abaixamento de $\mathrm{pH}$ de 3,77 para 3,64, e aumento de acidez titulável para 1,12\%.

Conforme se aumenta a temperatura de armazenamento, ocorre decréscimo no número de microrganismos do iogurte (Tamime et al., 1987). Uma diminuição significativa, no número de unidades formadoras de colônia (UFC) viáveis das culturas lácticas, presentes no iogurte ocorre quando este é armazenado por 14 dias a $10^{\circ} \mathrm{C}, 6$ dias a $15^{\circ} \mathrm{C}$ e 4 dias a $20^{\circ} \mathrm{C}$ (Shin et al., 1991). Estudando as alterações de $\mathrm{pH}$, acidez titulável e viabilidade das células lácticas e correlacionando-as com a aceitação do produto, Lee et al. (1991) concluíram que alterações toleráveis são observadas em 16 
dias a $5^{\circ} \mathrm{C}$ e $10^{\circ} \mathrm{C} ; 12$ dias a $15^{\circ} \mathrm{C}$ e 6 dias a $20^{\circ} \mathrm{C}$; o armazenamento acima de $30^{\circ} \mathrm{C}$ é impraticável.

Souza (1991), afirmou que o teor de sólidos do leite exerce grande influência na acidez titulável, e por isso, o pH é o melhor critério para se expressar a acidez do iogurte. Ainda, segundo o mesmo autor, a acidez do iogurte é muito variável, sendo largamente influenciada pelo paladar do consumidor. Valores de 0,7 a 1,25\% de ácido láctico ou pH de 4,6 a 3,7 são comuns. O ideal seria uma faixa de 0,7 a $0,9 \%$ ou pH de 4,4 a 4,0, na qual o produto não é insípido nem excessivamente ácido ou amargo. 


\section{MATERIAL E MÉTODOS}

\subsection{Aquisição das amostras}

Iogurtes do tipo natural, integral, de uma determinada marca comercial foram adquiridas diariamente, durante 30 dias consecutivos, perfazendo um total de 30 amostras, em um estabelecimento comercial de médio porte de Piracicaba - SP, onde o produto encontrava-se armazenado em estante refrigerada à temperatura entre 3 e $5{ }^{\circ} \mathrm{C}$. As amostras do produto foram levadas ao laboratório a partir do dia de recebimento pelo estabelecimento, sendo pertencentes ao mesmo lote e, portanto, com o mesmo prazo de validade.

\subsection{Preparo das amostras para análises}

As embalagens foram abertas, observando-se a aparência do produto, e a homogeneização foi realizada com bastão de vidro esterilizado, por cerca de 15 segundos (Brasil, 1981), em temperatura ambiente. 


\subsection{Peso bruto e peso líquido}

Foi determinado o peso bruto das amostras. As embalagens vazias foram lavadas com água destilada, secas, e pesadas. O peso da embalagem subtraído do peso bruto resultou no peso líquido expresso em gramas.

\subsection{Determinação de pH}

A determinação dos valores de $\mathrm{pH}$ foi realizada em potenciômetro digital, marca Digimed, modelo DMPH-2, calibrando-se o aparelho com soluções tampão, segundo indicado em Brasil (1981).

\subsection{Determinação da acidez titulável}

A acidez, expressa em ácido láctico, foi determinada através do método de titulação das amostras com solução de $\mathrm{NaOH} 0,1 \mathrm{~N}$, usando como indicador a solução de fenolftaleína 1,0\%, conforme metodologia descrita em A.O.A.C. (1980):

\subsection{Contagem de Lactobacillus sp e Streptococcus sp (em UFC/mL)}

As análises microbiológicas foram realizadas através de plaqueamentos de superfície, em duplicata, em meio de cultivo TPPY-Eriocromo ágar, sugerido por Bracquart (1981), cuja composição é: 
Meio TPPY Eriochrome Agar - Composição do meio de cultura/L:

- triptona: $7 \mathrm{~g}$

- proteose - peptona: $7 \mathrm{~g}$

- extrato de levedura: $2 \mathrm{~g}$

- glicose: $10 \mathrm{~g}$

- lactose: $10 \mathrm{~g}$

- Twen 80: $1 \mathrm{~g}$

- ágar: $15 \mathrm{~g}$

Em seguida, as placas foram incubadas em cubas de anaerobiose a $42^{\circ} \mathrm{C} \pm 1{ }^{\circ} \mathrm{C}$, por 48 h, utilizando-se o kit comercial Probac.

As contagens das unidades formadoras de colônias (UFC) foram realizadas em contador de colônias tipo Quebec, a fim de verificar a proporção apresentada pelas duas cepas lácticas.

\subsection{Contagem de microrganismos psicrófilos (em UFC/mL)}

Foram realizados plaqueamentos em meio de cultivo PCA (Plate Count Agar), preparado conforme descrito no Manual de Bacteriologia da DIFCO (Manual..., 1978), e cuja composição encontra-se abaixo.

Meio para contagem total (PCA) - Composição do meio de cultivo/L:

- triptona: $5 \mathrm{~g}$

- extrato de levedura: $2,5 \mathrm{~g}$

- dextrose: $1 \mathrm{~g}$

- ágar: $15 \mathrm{~g}$ 
Em seguida, procedeu-se à incubação em refrigerador a $7^{\circ} \mathrm{C}$, por 10 dias. As contagens foram realizadas em contador de colônias tipo Quebec. 


\section{RESULTADOS E DISCUSSÃO}

\subsection{Peso bruto e peso líquido dos produtos}

O peso bruto das amostras, determinado segundo o item 4.3. de Materiais e Métodos foi, em média, de 208,77g, sendo que os valores encontrados variaram entre $204,06 \mathrm{~g}$ e $212,67 \mathrm{~g}$.

Nenhuma das amostras, analisadas apresentou peso líquido abaixo daquele indicado na embalagem (200g). 


\subsection{Valores de $\mathrm{pH}$}

Os valores de $\mathrm{pH}$ dos iogurtes, logo após chegarem ao laboratório, são apresentados na Figura 2.

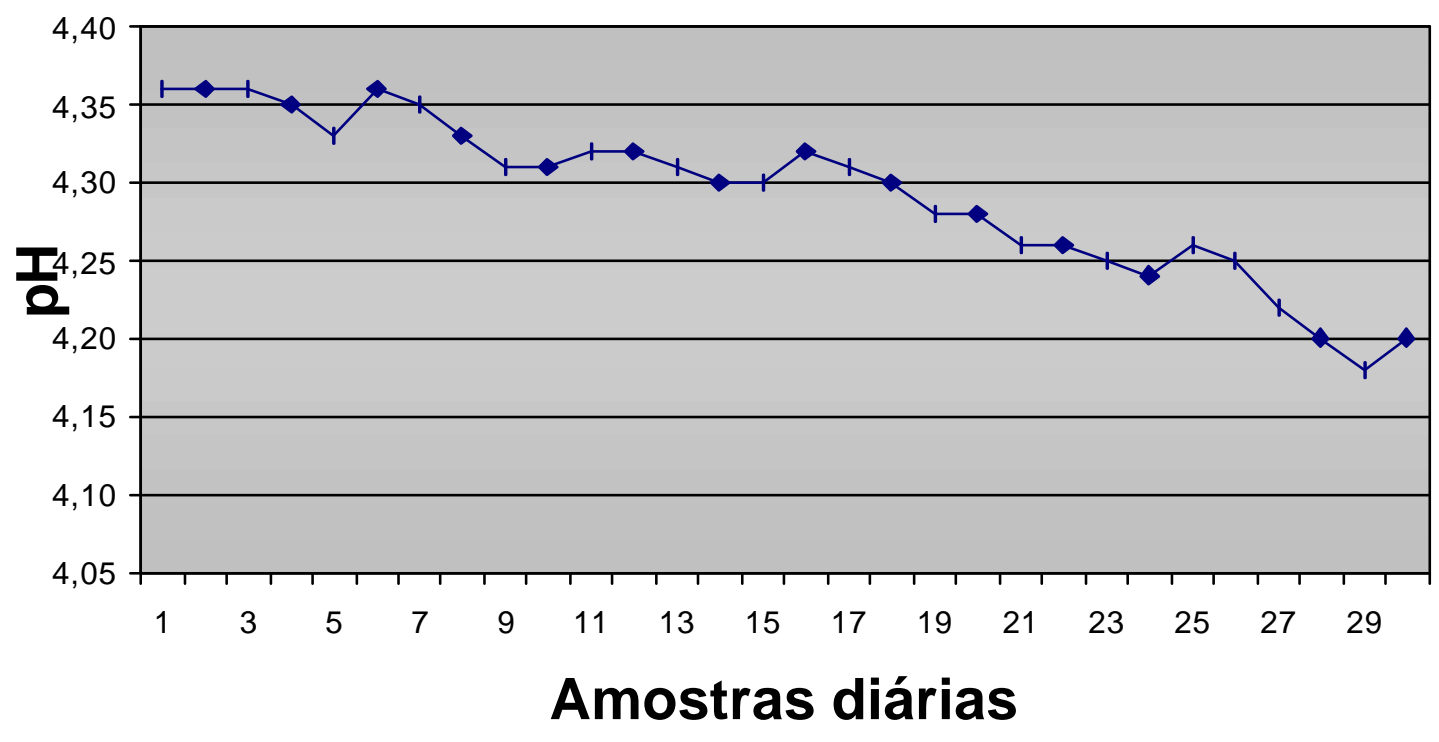

Figura 2 -Valores de $\mathrm{pH}$ nas amostras comerciais de iogurte. 
A literatura consultada mostra que não há concordância entre os autores, sobre o valor ideal ou a faixa de $\mathrm{pH}$, que o iogurte deve atingir ao final da incubação (fermentação).

De acordo com Brandão (1995), o pH costuma estar situado entre 4,4 e 4,2, embora possa apresentar valores tão baixos como 4,0. Já Sellars \& Babel (1970), informaram que o consumidor prefere o iogurte com pH em torno de 4,0. Kroger (1976), demonstrou que o pH entre 3,9 e 4,1 confere ao produto um sabor desagradável.

Uma faixa com valores de $\mathrm{pH}$ entre 3,7 e 4,6 é encontrada normalmente nos produtos, mas valores entre 4,4 e 4,0 são considerados mais próximos do ideal, uma vez que o produto nesta faixa de $\mathrm{pH}$ não se apresenta excessivamente amargo ou ácido (Souza, 1991).

Moreira (1998) analisou 4 marcas diferentes de iogurte, com e sem adição de polpa de frutas, e encontrou valores de $\mathrm{pH}$ nas amostras entre 3,76 e 4,39, diferindo estes valores entre os diferentes tipos de iogurte e lotes de fabricação. Todos os valores de $\mathrm{pH}$ das amostras analisadas tiveram uma tendência à apresentar valores abaixo do desejado, 4,2 - 4,5, faixa de $\mathrm{pH}$ segundo Abreu (1997).

Sendo assim, os valores determinados no momento da coleta, em média, encontram-se dentro da faixa de $\mathrm{pH}$ citada na literatura, ou seja, entre 4,4 e 4,0.

Pode-se, também, observar que, durante o período de comercialização do produto, houve uma diminuição dos valores de $\mathrm{pH}$, de 4,36 inicialmente, para 4,18, o que poderia caracterizar comprometimento da qualidade. Esta variação pode estar relacionada à temperatura de armazenamento do produto, assim como a oscilações na temperatura durante a comercialização do produto.

Em estudos realizados por Tealdo (1989), iogurtes foram armazenados a $4^{\circ} \mathrm{C}$ por 30 dias e foi observado um abaixamento de $\mathrm{pH}$ de 3,77 para 3,64. Outros estudos realizados por Gavin (1966) mostraram que o $\mathrm{pH}$ variou durante o armazenamento, baixando de 4,15 para 3,98 e de 4,62 para 4,15 (em iogurte tipo suave).

Tealdo (1989), concluiu que iogurtes armazenados a $4^{\circ} \mathrm{C}$ por 35 dias apresentaram uma diminuição significativa no valor de $\mathrm{pH}$, levando a uma menor aceitabilidade. 
Bellucci (1991) armazenou amostras de iogurtes do tipo natural a diferentes temperaturas $\left(3,7\right.$ e $\left.12^{\circ} \mathrm{C}\right)$ por 25 dias. Os resultados obtidos na pesquisa concordaram com os trabalhos de Diaz et al. (1989), Jordano et al. (1988), Salji et al. (1987) e Sinha et al. (1989) que observaram diminuição dos valores de $\mathrm{pH}$ do iogurte natural a medida que se aumentava o tempo e/ou a temperatura de armazenamento. Observou, também, que a redução do $\mathrm{pH}$ foi mais acentuada nos dez primeiros dias de armazenamento para todos os tratamentos empregados, o que pode ter ocorrido também no presente caso, observando conjuntamente a acidez titulável.

Gurgel (1994) concluiu que a variação na temperatura de armazenamento pode provocar alterações indesejáveis nas características físico-químicas do iogurte, diminuindo assim sua qualidade. A faixa de temperatura ideal para a conservação do iogurte, segundo o mesmo autor, é entre 3 e $5^{\circ} \mathrm{C}$. 


\subsection{Acidez Titulável}

Os resultados obtidos para acidez titulável inicial, expressa em \% de ácido láctico, em iogurtes comerciais são apresentados na Figura 3.

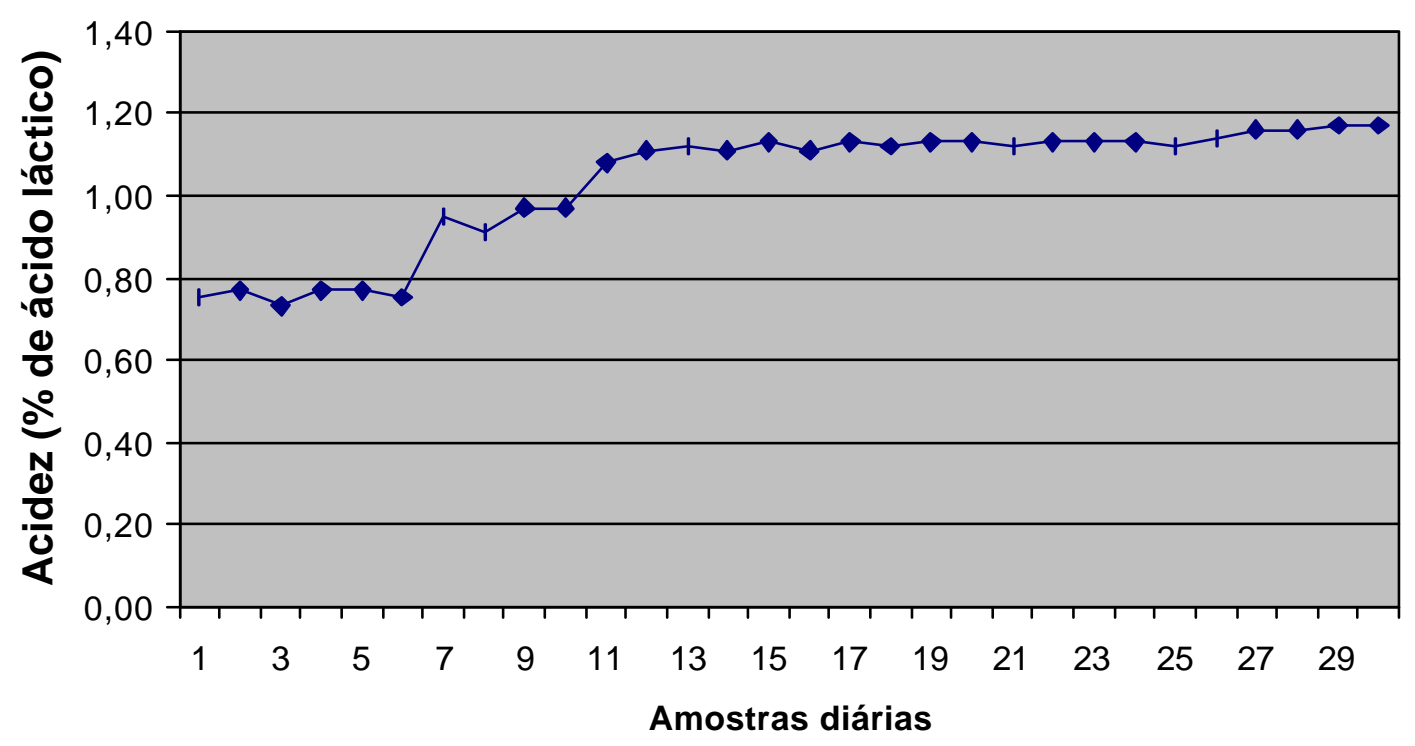

Figura 3 - Acidez titulável, em \% de ácido láctico, de amostras de iogurte.

De acordo com a literatura, tanto o $\mathrm{pH}$ como a acidez titulável do iogurte, podem variar conforme as condições de elaboração e armazenamento. 
Para Humphreys \& Plunkett (1969), a acidez inicial deve ser de 1,0 a 1,25\%. Ginslov (1970) afirmou que a acidez deve ser menor que 1,2\%. Segundo Brandão (1995), imediatamente após sua produção, o iogurte deve apresentar uma acidez de 0,9 a $1,0 \%$.

Valores entre 0,7 e 1,25\% são comuns, sendo ideal a faixa de acidez entre 0,7 e 0,9\% (Souza, 1991). Já para Tamime \& Robinson (1991), o desejável para o iogurte é apresentar uma acidez em torno de 0,72-1,17\% de ácido láctico.

Ao se comparar os valores obtidos no experimento, que variaram entre $0,73 \mathrm{e}$ 1,17\% em ácido láctico, com os valores apontados na literatura, pode-se constatar que estes estão dentro da faixa de acidez citada pelos autores.

Por outro lado, a variação ocorrida durante o período de comercialização do produto levou a obtenção de valores próximos ao limite apontado na literatura $(1,25 \%)$ (Humphreys \& Plunkett, 1969; Ginslov, 1970; Tamime \& Robinson, 1991).

Moreira (1998) analisou diferentes tipos de iogurte fabricados na região de Lavras - MG e encontrou, em sua pesquisa, acidez em torno de $1 \%$, e em dois tratamentos a acidez atingiu concentração de até 1,2\% de ácido láctico, embora o desejável seja o iogurte apresentar acidez em torno de 0,70 - 0,72\% de ácido láctico segundo Abreu (1997).

Para Bellucci (1991) o aumento de acidez titulável, em seu experimento, foi diretamente proporcional à temperatura de armazenamento. À temperatura de $12^{\circ} \mathrm{C}$ todos os tratamentos produziram valores maiores de acidez titulável do que à temperatura de $3^{\circ} \mathrm{C}$.

Vários são os fatores que podem causar esta variação de acidez, entre eles estão o processamento inadequado e ausência de controle da temperatura durante o armazenamento (Brandão, 1995).

Tealdo (1989), verificou uma menor aceitação do produto quando este atingiu valores a partir de $1,12 \%$ de ácido láctico, durante o armazenamento. Para Tamime \& Robinson (1991), o desenvolvimento de acidez no iogurte não deve ultrapassar valores de $1,17 \%$, após o armazenamento, valor este encontrado em amostra no experimento. 
O aumento da acidez titulável é diretamente proporcional a temperatura e ao tempo de armazenamento (Salinas, 1986).

Estudos realizados por Salji \& Ismail (1983) mostraram que em iogurtes armazenados sob refrigeração, a acidez titulável pode apresentar alterações em maior ou menor grau, dependendo do valor inicial da mesma, da temperatura de refrigeração, do tempo de armazenamento e do poder de pós-acidificação das culturas utilizadas.

Tamime \& Robinson (1991) definem pós-acificação como sendo a acidez produzida após o período de incubação, isto é, durante o resfriamento, armazenamento e distribuição, até o consumo do produto.

Os parâmetros da acidez titulável são importantes indicadores de qualidade para o iogurte, uma vez que, se excessivos, podem denotar más condições de armazenamento. Este problema pode ser reduzido e até solucionado, com uma adequada manutenção das condições ideais de temperatura, durante o armazenamento do produto, evitando assim, outras modificações no iogurte como desenvolvimento de microrganismos tolerantes à acidez, e alterações organolépticas que comprometem a qualidade e comercialização do iogurte. No presente caso, os valores de acidez titulável aumentaram nos dez primeiros dias a valores muito próximos de perda de qualidade levantada por diversos autores já citados.

\subsection{Contagem de Streptococcus sp e Lactobacillus sp (em UFC/mL).}

A utilização do meio de cultura TPPY - Eriocromo Ágar, pela presença do corante eriocromo em sua composição, possibilita a distinção entre as duas espécies, uma vez que as colônias de Streptococcus sp apresentaram-se circulares, opacas, violetas, com o centro escuro, e as colônias de Lactobacillus $s p$ apresentaram-se transparentes, de forma irregular, e não apresentaram alteração de coloração.

A proporção entre cocos e bacilos na cultura do iogurte é, normalmente, de 1:1 ou 2:1 (cocos:bacilos), e é evidente que o equilíbrio entre estes pode ser quebrado com 
facilidade, a menos que variáveis como as quantidades inoculadas, tempo e temperatura de armazenamento se mantenham sob estrito controle (Brandão, 1995).

Vários autores estudaram a proporcionalidade adequada entre os microrganismos citados para a fabricação de iogurte. Stocklin (1969), recomendou que seja de 1:1 ou 1:2. Lee et al. (1974), Platt (1969), Robinson \& Tamime (1975) e Sellars \& Babel (1970), sugeriram que seja de 1:1. Kapac-Parkaceva et al. (1975), afirmaram que a razão de 1:1 no iogurte produz uma quantidade substancialmente maior de aminoácidos livres, do que quando a razão 1:3 é usada.

Em relação à elaboração do iogurte, alguns autores, anteriormente citados, adotam que o produto deva conter proporções, aproximadamente, iguais entre as culturas lácticas. Para isso, é necessário um rigoroso controle durante a produção, e um constante acompanhamento da viabilidade das culturas lácticas.

Os resultados obtidos na enumeração de Streptococcus sp e Lactobacillus sp (em UFC/mL) são apresentados na Figura 4. 


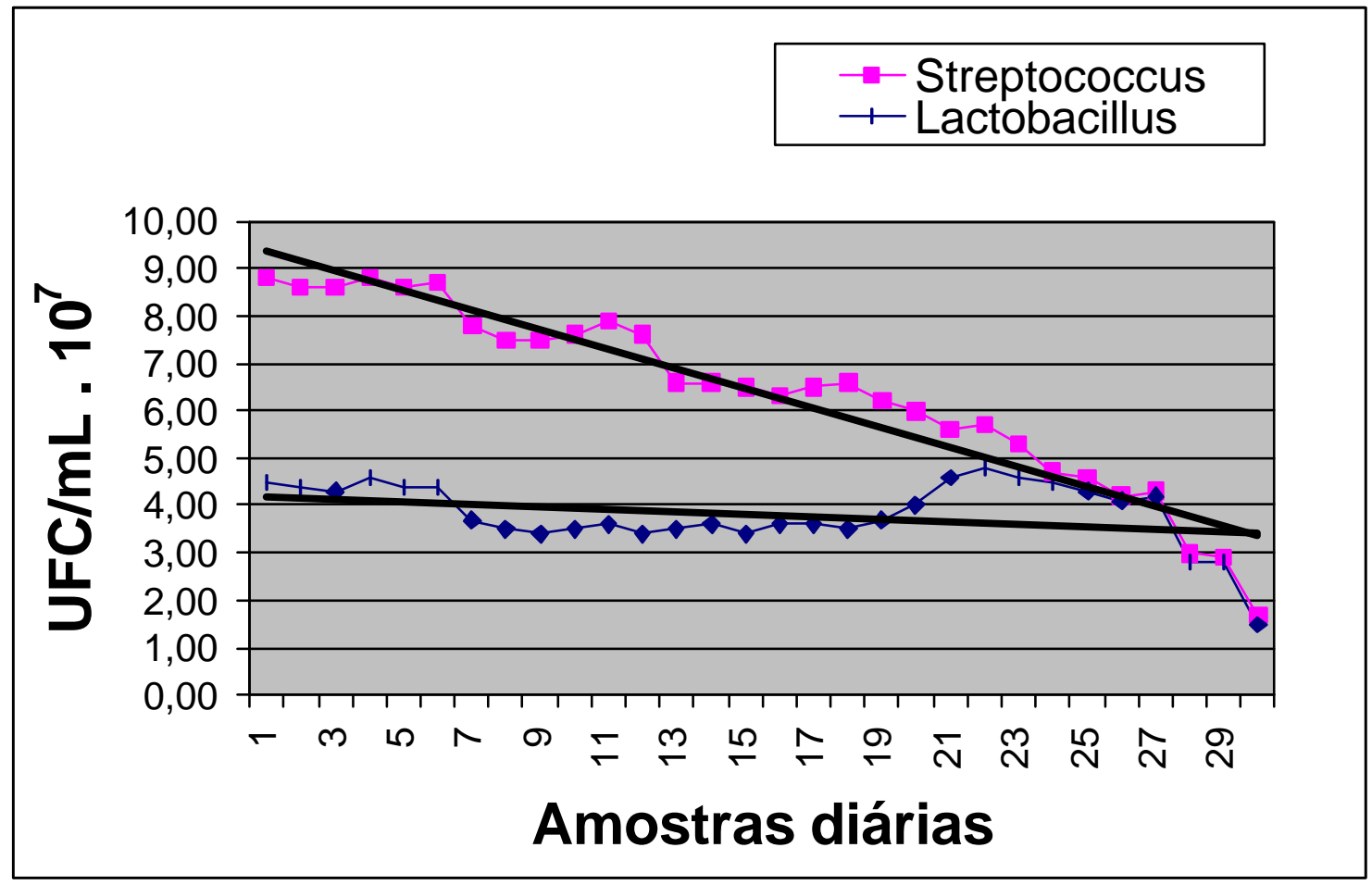

Figura 4 - UFC/mL de Streptococcus sp. E Lactobacillus sp.

A proporção inicial entre cocos:bacilos encontrada foi de, aproximadamente, 2:1, e da ordem de $10^{7} \mathrm{UFC} / \mathrm{mL}$. Esta proporção manteve-se até valores de $\mathrm{pH}$ e acidez em 4,32 e $1,12 \%$, respectivamente.

Com o aumento da acidez titulável e conseqüente queda dos valores de $\mathrm{pH}$, esta proporção reduziu para próxima de 1:1.

Arnott et al. (1974) mostraram a relação existente entre o pH e o desenvolvimento de microrganismos. Ao final do período de fermentação do leite, deve ser encontrada uma proporção de lactobacilo / estreptococo de 1:1, quando o valor de pH é em torno de 4,2-4,5.

Saboya et al. (1997), discutiram que Streptococcus salivarius subsp. thermophilus tem seu crescimento inibido a partir de $\mathrm{pH} 4,2$, mas o Lactobacillus 
delbrueckii subsp. bulgaricus tolera valores de $\mathrm{pH}$ entre 3,5 - 3,8. Desse modo os lactobacilos toleram, mais facilmente, valores de $\mathrm{pH}$ mais baixos e tendem a superar a população de lactococos quando o valor de $\mathrm{pH}$ encontra-se mais próximo de 4,0.

A proporção cocos:bacilos em $\mathrm{pH}$ em torno de 4,2 - 4,5 deve ser de 1:1 (Tamime et al., 1987).

Moreira (1998), em sua pesquisa não encontrou a proporção 1:1 nos iogurtes analisados. A proporção 1:2 ocorreu em 16,67\% das amostras. No restante das amostras $(83,33 \%)$ estreptococos foram predominantes, encontrando variações desde 1:4 à 1:2,3.

De acordo com Tamime \& Robinson (1991) o valor de $\mathrm{pH}$ implica na atividade metabólica das bactérias, podendo favorecer um determinado grupo, em detrimento de outro. No caso do iogurte, bactérias do gênero Lactobacillus crescem e toleram valores de $\mathrm{pH}$ mais baixos do que as pertencentes ao gênero Streptococcus.

Tamine et al. (1987), observaram que o número de bactérias lácticas no iogurte decresce quando se eleva a temperatura de armazenamento.

Ao correlacionar alterações de valores de $\mathrm{pH}$ durante o armazenamento à diferentes temperaturas, Shin et al. (1991) e Sinha et al. (1989), verificaram que, apesar das colônias de Lactobacillus delbrueckii sbsp. Bulgaricus apresentarem-se em maior número, ocorreu um decréscimo das duas culturas, concluindo, portanto, que a sobrevivência dessas culturas depende da habilidade de se manter o $\mathrm{pH}$ em valores mais altos durante o armazenamento.

Assim, pode-se perceber que nas amostras analisadas, a proporção que inicialmente era de, aproximadamente, 2:1 (cocos:bacilos), passou para, aproximadamente, 1:1 devido às variações sofridas nos valores de $\mathrm{pH}$ e acidez titulável, possivelmente ocasionadas por oscilações ocorridas na temperatura de comercialização do produto. 


\subsection{Contagem de Microrganismos psicrófilos}

Esta análise possibilita a verificação da presença de contaminantes e constatação da ocorrência de oscilações de temperatura, favorecendo o desenvolvimento de outros microrganismos, durante o armazenamento, o que levaria a possíveis alterações físico-químicas e à perda de qualidade do iogurte.

Não houve crescimento de microrganismos no meio PCA utilizado durante o período de incubação (10 dias).

Sendo assim, pode-se inferir que o produto não apresentava microrganismos psicrófilos contaminantes, o que demonstra que procedimentos adequados foram observados durante a sua produção, como era esperado para produtos comerciais, submetidos à legislação vigente (Brasil, 1998). 


\section{CONCLUSÕES}

Com base nas análises realizadas, mediante os resultados obtidos, pode-se concluir que:

- A proporção cocos:bacilos de, aproximadamente, 2:1 no produto comercial, foi alterada para, aproximadamente, 1:1, devido, provavelmente, às variações de $\mathrm{pH}$ e acidez durante o armazenamento, por trinta dias, permitindo a manutenção do gênero Lactobacillus mas reduzindo, entretanto, o gênero Streptococcus.

- O gênero Lactobacillus apresentou maior estabilidade nas condições encontradas durante o armazenamento que o gênero Streptococcus.

- Houve redução do pH e aumento da acidez titulável do iogurte durante o período de armazenagem para comercialização do produto.

- Ao final dos trinta dias de armazenamento, tanto o $\mathrm{pH}$ como a acidez titulável, mantiveram-se dentro de valores próprios para o iogurte, demonstrando que o prazo de validade indicado pelo fabricante é adequado. 
ANEXOS 
ANEXO A - Valores de Peso Bruto das amostras comerciais de iogurte.

\begin{tabular}{|c|c|}
\hline Amostra & Peso Bruto (g) \\
\hline 1 & 206.14 \\
\hline 2 & 208.48 \\
\hline 3 & 205.60 \\
\hline 4 & 210.09 \\
\hline 5 & 209.61 \\
\hline 6 & 212.63 \\
\hline 7 & 204.65 \\
\hline 8 & 204.06 \\
\hline 9 & 207.48 \\
\hline 10 & 204.21 \\
\hline 11 & 207.49 \\
\hline 12 & 207.92 \\
\hline 13 & 211.01 \\
\hline 14 & 208.04 \\
\hline 15 & 209.08 \\
\hline 16 & 212.67 \\
\hline 17 & 208.88 \\
\hline 18 & 210.35 \\
\hline 19 & 208.13 \\
\hline 20 & 208.64 \\
\hline 21 & 212.37 \\
\hline 22 & 210.32 \\
\hline 23 & 209.83 \\
\hline 24 & 210.35 \\
\hline 25 & 208.54 \\
\hline 26 & 209.64 \\
\hline 27 & 208.32 \\
\hline 28 & 207.98 \\
\hline 29 & 210.84 \\
\hline 30 & 209.75 \\
\hline
\end{tabular}


ANEXO B - Valores de pH das amostras comerciais de iogurte.

\begin{tabular}{|c|c|}
\hline Amostra & $\mathrm{pH}$ \\
\hline 1 & 4.36 \\
\hline 2 & 4.36 \\
\hline 3 & 4.36 \\
\hline 4 & 4.35 \\
\hline 5 & 4.33 \\
\hline 6 & 4.36 \\
\hline 7 & 4.35 \\
\hline 8 & 4.33 \\
\hline 9 & 4.31 \\
\hline 10 & 4.31 \\
\hline 11 & 4.32 \\
\hline 12 & 4.32 \\
\hline 13 & 4.31 \\
\hline 14 & 4.30 \\
\hline 15 & 4.30 \\
\hline 16 & 4.32 \\
\hline 17 & 4.31 \\
\hline 18 & 4.30 \\
\hline 19 & 4.28 \\
\hline 20 & 4.28 \\
\hline 21 & 4.26 \\
\hline 22 & 4.26 \\
\hline 23 & 4.25 \\
\hline 24 & 4.24 \\
\hline 25 & 4.26 \\
\hline 26 & 4.25 \\
\hline 27 & 4.22 \\
\hline 28 & 4.20 \\
\hline 29 & 4.18 \\
\hline 30 & 4.20 \\
\hline
\end{tabular}


ANEXO C - Valores de acidez titulável das amostras de iogurte.

\begin{tabular}{|c|c|}
\hline Amostra & $\begin{array}{l}\text { Acidez (em \% de } \\
\text { ácido láctico) }\end{array}$ \\
\hline 1 & 0.75 \\
\hline 2 & 0.77 \\
\hline 3 & 0.73 \\
\hline 4 & 0.77 \\
\hline 5 & 0.77 \\
\hline 6 & 0.75 \\
\hline 7 & 0.95 \\
\hline 8 & 0.91 \\
\hline 9 & 0.97 \\
\hline 10 & 0.97 \\
\hline 11 & 1.08 \\
\hline 12 & 1.11 \\
\hline 13 & 1.12 \\
\hline 14 & 1.11 \\
\hline 15 & 1.13 \\
\hline 16 & 1.11 \\
\hline 17 & 1.13 \\
\hline 18 & 1.12 \\
\hline 19 & 1.13 \\
\hline 20 & 1.13 \\
\hline 21 & 1.12 \\
\hline 22 & 1.13 \\
\hline 23 & 1.13 \\
\hline 24 & 1.13 \\
\hline 25 & 1.12 \\
\hline 26 & 1.14 \\
\hline 27 & 1.16 \\
\hline 28 & 1.16 \\
\hline 29 & 1.17 \\
\hline 30 & 1.17 \\
\hline
\end{tabular}


ANEXO D - Contagem de Streptococcus sp. e Lactobacillus sp em UFC/mL x $10^{7}$.

\begin{tabular}{|c|c|c|}
\hline Amostra & cocos & Bacilos \\
\hline 1 & 8.8 & 4.5 \\
\hline 2 & 8.6 & 4.4 \\
\hline 3 & 8.6 & 4.3 \\
\hline 4 & 8.8 & 4.6 \\
\hline 5 & 8.6 & 4.4 \\
\hline 6 & 8.7 & 4.4 \\
\hline 7 & 7.8 & 3.7 \\
\hline 8 & 7.5 & 3.5 \\
\hline 9 & 7.5 & 3.4 \\
\hline 10 & 7.6 & 3.5 \\
\hline 11 & 7.9 & 3.6 \\
\hline 12 & 7.6 & 3.4 \\
\hline 13 & 6.6 & 3.5 \\
\hline 14 & 6.6 & 3.6 \\
\hline 15 & 6.5 & 3.4 \\
\hline 16 & 6.3 & 3.6 \\
\hline 17 & 6.5 & 3.6 \\
\hline 18 & 6.6 & 3.5 \\
\hline 19 & 6.2 & 3.7 \\
\hline 20 & 6.0 & 4.0 \\
\hline 21 & 5.6 & 4.6 \\
\hline 22 & 5.7 & 4.8 \\
\hline 23 & 5.3 & 4.6 \\
\hline 24 & 4.7 & 4.5 \\
\hline 25 & 4.6 & 4.3 \\
\hline 26 & 4.2 & 4.1 \\
\hline 27 & 4.3 & 4.2 \\
\hline 28 & 3.0 & 2.8 \\
\hline 29 & 2.9 & 2.8 \\
\hline 30 & 1.7 & 1.5 \\
\hline & & \\
\hline
\end{tabular}




\section{REFERÊNCIAS BIBLIOGRÁFICAS}

ABREU, L. R. de. Tecnologia e aproveitamento do leite. Lavras: FAEPE, 1997. 149p.

ARAÚJO, W. M. C.; FREITAS, C.P. de.; PIRES, E. M. F. et al. Utilização de leite de cabra na elaboração de iogurte. Revista do Instituto de Laticínios Cândido Tostes, v.41, n.247, p.37-40, 1986.

ARNOTT, D. R.; DUITSCHAEVER, C. R.; BULLOCK, D. H. Microbiological evaluation of yogurt produced commercially in Ontario. Journal Milk, Food Technology, v.37, n.1, p.11-13, 1974.

ASPERGER, H. Applicability of analytical methods for the assessment of yogurt quality. Dairy Science Abstract, v.5, n.39, p.123-145, 1977.

ASSOCIATION OF AFFICIAL ANALYTICAL CHEMISTS. Official methods of analysis. 16. ed. Washington: AOAC, 1995. 2v.

BEHMER, M. L. A. Tecnologia do leite. São Paulo: Nobel, 1984. 320p.

BEHMER, M. L. A. Tecnologia do leite: produção, industrialização e análise. 15.ed. São Paulo: Nobel, 1991. 320p. 
BELLUCCI, V. L. Efeito das condições de armazenamento no $\mathrm{pH}$, acidez titulável, sobrevivência e atividade proteolítica de culturas lácticas. Piracicaba, 1991. 102p.

Dissertação (Mestrado) - Escola Superior de Agricultura "Luiz de Queiroz", Universidade de São Paulo.

BLUMER, E. Iogurte: obtenção e aspectos microbiológicos. Piracicaba: ESALQ, Depto. Tecnologia Rural, 1989. 20p.

BRACQUART, P. An Agar medium for the differential enumeration of Streptococcus thermophilus and Lactobacillus bulgaricus in yogurt. Journal of Applied Bacteriology, v.51, n.2, p.303-305, 1981.

BRANDÃO, S. C. C. Tecnologia da produção industrial de iogurte. Leite \& Derivados, v.4, n.25, p.24-38, 1995.

BRASIL. Leis, decretos, etc. Decreto $n^{0} 30.691$ de 29 de março 1952. Diário Oficial, 7 jul. 1952. Col 1, p. 010785. Regulamento da inspeção industrial e sanitária de produtos de origem animal.

BRASIL. Ministério da Agricultura. Secretaria Nacional de Defesa Agropecuária. Laboratório Nacional de Referência Animal. Métodos analíticos oficiais para controle de produtos de origem animal e seus ingredientes II - Métodos físicos e químicos. Brasília, 1981.

BRASIL. Leis, decretos, etc. Nova legislação de produtos lácteos e de alimentos especiais, diet e enriquecidos. São Paulo: Fonte, 1998. 212p.

BOUDIER, J. F.; COLIN, J. Y.; SOTTIEZ, P. Yoghurt: based sauces and their manufacture, 1989. French Patent Application FR 2623376 A 1. 
CARUSO, J. G. B.; OLIVEIRA, A. J. Leite: obtenção, controle de qualidade e processamento. São Paulo: Secretaria da Indústria e Comércio, Ciência e Tecnologia, 1984. 162p.

CONSUMO de iogurte. Leite B, v.11, n.123, p.6, 1997.

DAVIS, J. G. Laboratory control of yogurt. Dairy Industries, v.35, n.3, p.139-44, 1970 .

DEETH, H. C.; TAMINE, A. Y. Yogurt: nutritive and terapeutic aspects. Journal Food Protection, v.44, n.1, p.78-96, 1981.

DELlAGLIO, F.; TORRIANI, S.; VLAEMINCK, G. et al. Specific characteristics of microorganisms used for fermented milks. Bulletin International Dairy Federation, n.277, p.4-16, 1992.

DÍAZ, M. C. P.; PADRÓN, G. A.; MARANTE, R. A. Evolution de los microrganismos de interesis higienico-sanitario en yogurtes comerciales. Alimentaria, v.26, n.205, p.51-55, 1989.

DIFCO. Manual de microbiologia: recopilación de técnicas. Michigan: DIFCO Laboratories, 1978. 395p.

DRIESSEN, F. M.; KINGMA, F.; STADHOUDERS, J. Evidence that Lactobacillus bulgaricus in yogurt is stimulated by carbon dioxide produced by Streptococcus thermophillus. Netherlands Milk Dairy Journal, v.36, n.2, p.135-44, 1982.

FERREIRA, C. L. L. F. Determinação do teor de niacina em iogurte preparado com culturas starters contendo microrganismos diferentes. Revista do Instituto de Laticínios Cândido Tostes, v.36, n.214, p.39-42, 1981. 
FERREIRA, C. L. L. F.; CHAVES, J. B. P. Caracterização do iogurte comercializado na zona da mata, Minas Gerais. Revista do Instituto de Laticínios Cândido Tostes, v.36, n.218, p.27-32, 1981.

FOSTER, T. L.; WINANS, L.; CARSKI, T. R. Evaluation of Lactobacillus preparations of enterotoxigenic Escherichia coli - induced rabbit illeal 1 oop reactions. American Journal Gastroenterology, v.73, p.238-243, 1980.

GARCIA, S.; VALLE, J. L. E. do. Obtenção de fermentos láticos termófilos para a utilização em iogurte. Boletim do Instituto de Tecnologia de Alimentos, v.23, n.1, p.61-85, 1986.

GASSEM, M.; FRANK, J. F. Effect of protein degradation of milk on the physical and chemical properties of yogurt. Journal of Dairy Science, v.73, n.1, p.114-119, 1990.

GAVIN, M. The combined effect of temperature and acidity on the keeping quality of yogurt. Milchwissenschaft, n.21, p.85-7, 1966.

GINSLOV, B. O. Modern tends in yogurt manufacture in South African. Journal of Dairy Tecnology, v.2, p.70-83, 1970.

GURGEL, M. S. C. C. A.; OLIVEIRA, A. J.; CAMARGO, R. Microbiologia do iogurte. Piracicaba: ESALQ, Depto. de Ciência e Tecnologia de Alimentos, 1992. $23 p$.

GURGEL, M. S. C. C. A. Teor de tirosina como parâmetro das alterações físico químicas do iogurte. Piracicaba, 1994. 82p. Dissertação (Mestrado) - Escola Superior de Agricultura "Luiz de Queiroz", Universidade de São Paulo. 
HUMPHREYS, C. L.; PLUNKETT, M. Yogurt: a review of its manufacture. Dairy Science Abstract, v.2, n.31, p.607-22, 1969.

IGARASHI, Y. Enchanesment of proteolysis in bovine skim milk by heat and chemical treatments. Journal of Dairy Research, v.57, n.4, p.541-548, 1990.

IOGURTES e bebidas lácticas. Alimentos e Tecnologia, v.9, n.57, p.20-51, 1995.

JORDANO, R.; MARTINEZ, P.; GARRIDO, M. D. et al. Changes of acidity and pH in commercial yogurt. Alimentaria, v.25, n.189, p.61-64, 1988.

JUFFS, H. S. Proteolysis detection in milk. Journal of Dairy Research, v.42, n.6, p.31-41, 1975.

KAPAC-PARKACEVA, N.; BAUER, O.; CIZBANOSKI, T. Effects of differents ratios of starter bacteria on amino acids, spectrum in yogurt made from cow's milk. Dairy Science Abstrcts, v.37, n.11, p.17-22, 1975.

KLEINMAN, R. E. Practical significance of lactose intolerance in children: supplement. Pediatric, v.86, n.4, p.643-644, 1990.

KROGER, M. Quality of yogurt (Review). Journal of Dairy Science, v.59, n.2, p.344-50, 1976.

LEE, S. Y.; VEDAMUTHU, E. R.; WASHAM, C. J. et al. An agar medium for the differential enumeration of yogurt starter bacteria. Journal of Milk and Food Technology, v.37, n.5, p.272-276, 1974. 
LEE, J. J.; KIM, H. Y.; SHIN, J. B.; BAEK, Y. J. Studies on the changes of the physical properties and the shelf-life of liquid yogurt stored at different temperatures. Journal of Dairy Science, v.13, n.2, p.124-31, 1991.

LIN, M.; SAVIANO, D.; HARLANDER, S. Influence of nonfermented dairy products containing bacterial starter cultures on lactose maldigestion in humans. Journal of Dairy Science, v.74, p.87-95, 1991.

LOEWENSTEIN, M.; EPSCK, S. J.; BARNHART, H. M. et al. Research on goat milk products: a review. Journal of Dairy Science, v.63, n.10, p.1631-1648, 1980.

MOREIRA, S. R. Caracterização microbiológica de iogurtes comercializados em Lavras - MG. Lavras, 1998. 72p. Dissertação (M. S.) - Universidade Federal de Lavras.

MORENO, V.; KOSIKOWSKI, F. V. Peptides, aminoacids and amines liberated from B-casein by micrococcal cell-free preparations. Journal of Dairy Science, v.56, n.19, p. 39, 1973.

NEIROTTI, E.; OLIVEIRA, A. J. Produção de iogurte pelo emprego de culturas lácticas mistas. Boletim da Sociedade Brasileira de Ciência e Tecnologia de Alimentos, v.22, n.1/2, p.1-16, 1988.

PENNA, A. L. B.; OLIVEIRA, M. N.; BARUFFALDI, R. Avaliação da qualidade de iogurtes. Leite \& Derivados, v.1, n.16, p.13-18, 1994.

PETTE, J. W.; LOLKEMA, H. Yogurt IV. Het evenwicht der bacteriesoorten in yogurt. Netherlands Milk and Dairy Journal, v.5, n.1, p.14-26, 1951. 
PLATT, D. Processing and merchandising of yogurt. Cultured of Dairy Products Journal, v.4, n.3, p.16-17, 1969.

POMBO, A. F. W.; GRANZINOLLI, G. G.; FERNANDES, R. M. Sólidos totais do leite, acidez, $\mathrm{pH}$ e viscosidade do iogurte. Revista do Instituto de Laticínios Cândido Tostes, v.38, n.227, p.19-24, 1983.

RADKE-MITCHELL, L. C.; SANDINI, W. E. Influence of temperature on associative growth of Streptococcus thermophilus and Lactobacillus bulgaricus. Journal of Dairy Science, v.69, n.10, p.2558-2568, 1986.

RASIC, J. L.; KURMANN, J. A. Yogurt: scientific grounds, technology manufacture and preparation. s. 1.: Technical Dairy Publishing House, 1978. 342p.

REDDY, G. V.; VEDAMUTHU, E.; WASHAM, C. J. et al. Associative growth studies in three-strain mixtures of lactic Streptococci. Applied Microbiology, v.24, n.6, p.953-957, 1972.

ROBINSON, R. K.; TAMIME, A. W. Yogurt: a review of the product and its manufacture. Journal of the Society of Dairy Technology, v.28, n.3, p.149-163, 1975.

SABOYA, L. V.; OETTERER, M.; OLIVEIRA, A. J. Propriedades profiláticas e terapêuticas de leites fermentados: uma revisão. Boletim da Sociedade Brasileira de Ciência e Tecnologia de Alimentos, v.31, n.2, p.176-185, 1997.

SALADO, G. A.; ANDRADE, M. O. de. Processamento e qualidade nutricional do iogurte. Boletim Cultural, v.7, p.1-35, 1989. 
SALINAS, R. J. Hygiene quality of commercial yoghurts. Alimentaria, v.178, n.15, p.27-30, 1986.

SALJI, J. P.; ISMAIL, A. A. Effect of initial acidity of plain yogurt on acidity changes during refrigerated storage. Journal Food Science, v.48, n.1, p.249-258, 1983.

SALJI, J. P.; SAADI, S. B.; MASHHADI, A. Self life of plain liquid yogurt manufactured in Saud Arabia. Journal of Food Protection, v.50, n.2, p.123-126, 1987.

SELLARS, R. L.; BABEL, F. J. Culture for the manufacture of dairy products. Wisconsin: Cristian Hansen's Laboratorium Incorporation, 1970. p.46-49.

SINGH, J.; SHARMA, D. K. Yogurt starters in skim milk-1-acid and flavour production and proteolytic activity by yogurt starters. Cultured Dairy Products Journal, v.11, n.2, p.22-25, 1982.

SHIN, J. G.; LEE, J. J.; KIM, H. Y.; BAEK, Y. J. Studies on the changes in quality and sensory evaluation of stirred yogurt stored at different temperatures. Korean Journal of Dairy Science, v.13, n.2, p.148-155, 1991.

SILVA, J. C. Leites fermentados: iogurte e acidófilo. Revista do Instituto de Laticínios Cândido Tostes, v.29, n.174-175, p.70-81, 1974.

SILVA, R. C. F. da. Iogurte. Piracicaba: ESALQ, Depto. Tecnologia Rural, 23p. 1985.

SINHA, R. P.; MODLER, H. W.; EMMONS, D. B. Changes in acidity and starter bacteria in commercial yogurts during storage. Cultured Dairy Products Journal, v.24, n.2, p.12-16, 1989. 
SLOCUM, S. A.; JASINKI, E. M.; ANANTHESWARAN, R. C. et al. Processing variables affecting the proteolitic activity of yogurt. Food Science Tecnology Abstracts, v.20, n.10, p. 125-139, 1988.

SOUZA, G. Fatores de qualidade do iogurte. Coletânea do Instituto de Tecnologia de Alimentos , v.21, n.1, p.20-27, 1991.

SOUZA, G. Iogurte: tecnologia, consumo e produção em alta. Leite \& Derivados, v.5, n.28, p. 44-54, 1996.

STOCKLIN, P. Production and hardling of yogurt on a commercial scale. Cultured Dairy Products Journal, v.4, n.3, p.6-10, 1969.

TAMIME, A. Y.; DEETH, H. C. Yogurt: technology and Biochemistry. Journal of Food Protection, v.43, n.12, p.939-77, 1980.

TAMIME, A. Y.; DAVIES, G.; HAMILTON, M. P. The quality of yogurt on retail sale in a Ayrshire. Part I. Chemical and microbiological evaluation. Dairy Industries International, v.52, n.6, p.19-21, 1987.

TAMIME, A. Y.; ROBINSON, R. K. Yogurt: science and technology. Oxford: Pergamon Press, 1985. 431p.

TAMIME, A. Y.; ROBINSON, R. K. Fermented milks and their future trends. Part II. Technological aspects. Journal of Dairy Research, v.55, n.2, p.281-307, 1988.

TAMIME, A. Y.; ROBINSON, R. K. Yogur: ciencia y tecnologia. Trad. de Maria de la Concepción Diáz de Villegas Soláns e Alvaro Rodriguez Sánchez Arévalo. Zaragoza: Acribia, 1991. 368p. 
TEALDO, E. Caratterizzatione chimico-fisica ed organolettica dello yogurt. Istituto de Tecnica e Sperimentazione Lattiero Caseria, v.18, n.30, p.122-141, 1989. 